We thank Professor B. O. Phinney for a gift of maize, and the Australian Universities Research Grants Committee for financial assistance.

R. C. Jennings

Department of Botany,

A. J. MCCOMB

University of Western Australia.

Rereived May 16, 1967

' Phinney, B. O., and West, (. A., Ann. Rev. Plunt Physiol., 11, 411 (1960). 'Mowat, J. A.: Botanica Mar., 8, 149 (1965).

${ }^{3}$ Radley, M., Noture, 191, 684 (1961).

${ }^{4}$ Mecomb. A. J., Nature, 192, 575 (1961).

Shinney, B. O), and West, C. P., Handb. Pf. Physiol., 14, 1189 (1961).

- MarMillan, J., Seaton, J. (., and Suter, P. J., Adw. Chem. Ser.. 28, 18 (1961).

7 Brian, P. W. Hemming. II. G., and Lowe, D., Ann. Bot. N.S., 28, 369 (1964).

"Kinoshita, s., and Teromoto, K., Bull. Jap. Soc. Phyeol., 6, 85 (1958).

'Iwasaki, H., J. Plant Cell Physiol., Tokyo, 6, 325 (1965).

\section{Effect of Light on Cell Division in Plant Tissue Cultures}

LIGHT strongly influences many aspects of growth in plants. There have, however, been few studies on the effects of light on cell division in non-green plant tissue cultures. In the course of investigating the physiology of cell division in developing callus cultures of Helianthus tuberosus it has been observed that light can have an inhibitory effect on cell division.

Observations ${ }^{1-3}$ have shown the course of change in cell number with time in explants taken from tubers of the Jerusalem artichoke and cultured in contact with a medium containing 20 per cent coconut milk and $10^{-6}$ molar, 2,4-dichlorophenoxyacetic acid. It has also been

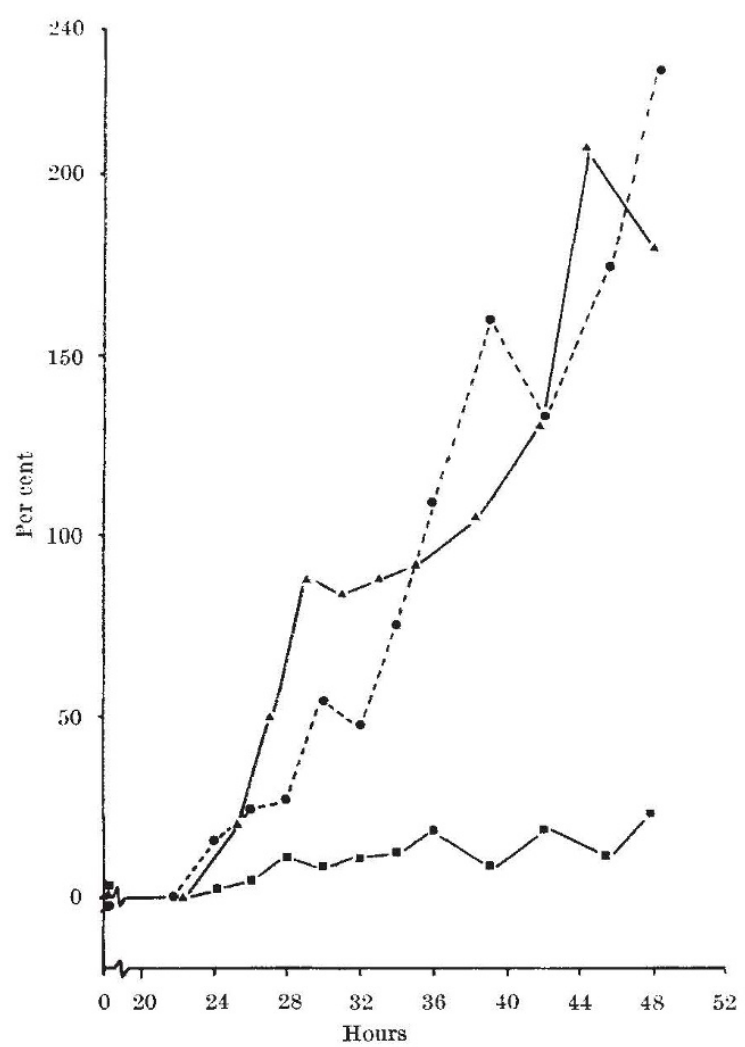

Fig. 1. Percentage increase in cell number per explant with time of incubation. Explants were removed from tubers in green light and cultured Petri dishes, at $25^{\circ} \mathrm{C}$. A qitation was on a reciprocating shaker operating at $50 \mathrm{c} / \mathrm{s}$ with a $7 \mathrm{~cm}$ displacement. The explants were grown in total darkness $(\boldsymbol{\Delta}), 120 \mathrm{ft}$.-candles $(\mathbf{O})$ and $\mathbf{4 5 0} \mathrm{ft}$.-candles $(\mathbf{B})$. Both light sources were mixed fluorescent and tungsten. Cell number data were derived from counts on 5 per cent chromic acid macerates of five explant samples.

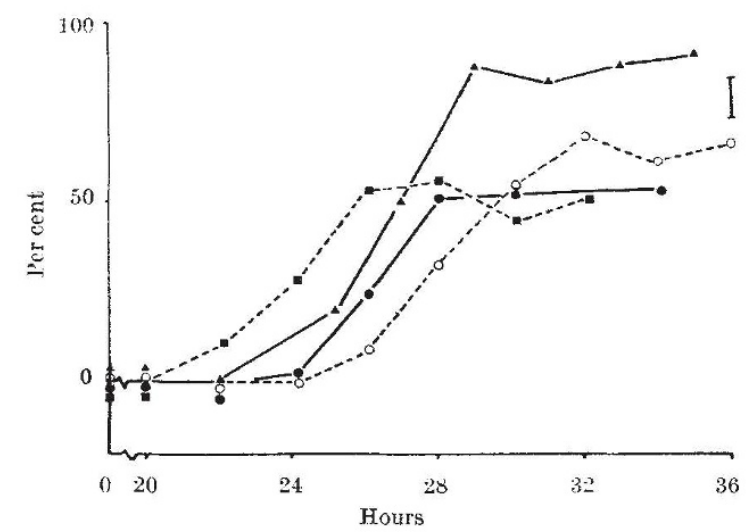

Fig. 2. Perecntage increase in cell number per explant with time of incubation. Explants were prepared and cultured as described in Fig 1 For the first $30 \mathrm{~min}$ after exeision, the explants were exposed to total darkness $(\mathbf{A}), 18 \mathrm{ft}$.-candles finorescent light $(0)$ and $120 \mathrm{ft}$-candles (-) and $450 \mathrm{ft}$.candles ( 5 ), mixed fluorescent and tungsten light. Subsequent culture was in total darkness. The vertical line represents the S.E. of the difference between the dark and light treatments.

shown ${ }^{2,3}$ that the first few divisions are synchronous. These observations were made with an experimental procedure which involved exposure of the tubers and of the excised explants for periods of $30-90 \mathrm{~min}$ to about $18 \mathrm{ft}$.-candles from a fluorescent source, and exposure to the light from a tungsten lamp when the cultures were being inspected. Subsequently it has been found that the proportion of cells in the explant that divide at the first synchronous division increases from 45 to 90 per cent when the explant is removed in low intensity green light and then cultured in total darkness on a medium without coconut milk but in the presence of $2: 4$-dichlorophenoxyacetic acid $(2,4-\mathrm{D})$ at $10^{-5} \mathrm{moles} / \mathrm{l}$.

Results of two experiments designed to show the light effect in division are given in Figs. 1 and 2. The explants were obtained with techniques described elsewhere ${ }^{1}$, and grown in bulk culture in a liquid medium.

In the first experiment (Fig. 1), the explants removed in low intensity green light were exposed throughout the period of culture to two intensities of light, and their growth compared with a control in total darkness. In the second experiment (Fig. 2), the explants were exposed to various light intensities for a period of $30 \mathrm{~min}$ after excision. They were then cultured in total darkness.

It is clear from the results presented in Fig. I that the number of cells formed at the first division is significantly greater in the dark than in the light. Continuous light therefore has a strongly depressing effect on cell division.

Preliminary exposure for a short period after excision has a sharply depressing effect on division at all light intensities (Fig. 2). The explants excised in green light and eultured in total darkness form considerably more cells at the first synchronous division than do those exposed to light for the first $30 \mathrm{~min}$ after excision. Clearly radiation other than dim green light has a strongly depressive effect on division in this system and most of the effect is exerted in the period immediately after excision. It may be noted that the synchronous pattern is displayed in all eonditions in this experimental series.

We thank Professor R. Brown and Dr J. E. Dale for their advice, and the Sir David Baxter Scholarship Fund for a studentship to one of us (R. S. S. F.).

R. S. S. FraSER

U. E. Lotning

Department of Botany,

M. M. YEOMAN

University of Edinburgh.

Received May 30; revised Jnly 5, 1967.

1 Yeoman, M. M., Dyer, A. F, and Robertson, A. I., Ann. Bot., 29, 265 (1965).

${ }^{2}$ Yeoman, M. M., Evans, P. K., and Naik, G. G., Nature, 209, 1115 (1966).

${ }^{3}$ Yeoman, M. M., and Evans, P. K., Ann. Bot., 31, $323(196 \pi)$. 